\title{
Recombinant bromelain production in Escherichia coli: process optimization in shake flask culture by response surface methodology
}

\author{
Bala Muntari ${ }^{1,2}$, Azura Amid ${ }^{1}$, Maizirwan Mel ${ }^{1}$, Mohammed S Jami ${ }^{1}$ and Hamzah M Salleh ${ }^{\text {* }}$
}

\begin{abstract}
Bromelain, a cysteine protease with various therapeutic and industrial applications, was expressed in Escherichia coli, BL21-Al clone, under different cultivation conditions (post-induction temperature, L-arabinose concentration and post-induction period). The optimized conditions by response surface methodology using face centered central composite design were $0.2 \%(\mathrm{w} / \mathrm{V}) \mathrm{L}$-arabinose, $8 \mathrm{hr}$ and $25^{\circ} \mathrm{C}$. The analysis of variance coupled with larger value of $R^{2}(0.989)$ showed that the quadratic model used for the prediction was highly significant $(p<0.05)$. Under the optimized conditions, the model produced bromelain activity of $9.2 \mathrm{U} / \mathrm{mg}$ while validation experiments gave bromelain activity of $9.6 \pm 0.02 \mathrm{U} / \mathrm{mg}$ at $0.15 \%(\mathrm{w} / \mathrm{V})$ L-arabinose, $8 \mathrm{hr}$ and $27^{\circ} \mathrm{C}$. This study had innovatively developed cultivation conditions for better production of recombinant bromelain in shake flask culture.
\end{abstract}

Keywords: bromelain, Escherichia coli BL21-Al, face centered central composite design, induction.

\section{Introduction}

The use of highly purified proteins for therapeutic purposes has been in existence for many decades (Paul, 2004,). Enzymes, mostly proteases, constitute the largest portion of these purified proteins for industrial and therapeutic applications. Proteases are enzymes that catalyze the hydrolysis of peptide linkages in proteins. They have wide applications in food, pharmaceutical and detergent industries. In fact, these enzymes constitute about $60 \%$ of all commercial enzymes in the world (Lucia and Tomas, 2010,). Recently, microbial enzymes have been substituting those from other sources and might now account for almost $90 \%$ of the total market (Illanes, 2008,). This is due to the fact that microbial cells are excellent systems for enzyme production. Thus, there is a great stimulation for extensive research works on recombinant proteins (Illanes, 2008).

Bromelain is a general name given to the family of sulfhydryl proteolytic enzymes (cysteine proteases) obtained from the pineapple plant, Ananas comosus.

\footnotetext{
* Correspondence: hamzah@iium.edu.my

'Bioprocess and Molecular Engineering Research Unit, Department of Biotechnology Engineering, Faculty of Engineering, International Islamic University Malaysia, P.O. Box 10, 50728, Kuala Lumpur, Malaysia Full list of author information is available at the end of the article
}

Depending on the source, it is usually classified as either fruit bromelain or stem bromelain (Kelly 1996,). The sulfhydryl proteolytic fraction is the primary component of bromelain. The pineapple enzyme also contains several protease inhibitors, a peroxidase, acid phosphatase, and organically bound calcium (Kelly, 1996).

A member of papain family, stem bromelain (E. C.3.4.22.32) contains 212 amino acid residues including seven cysteines, one of which is involved in catalysis (Bitange et al., 2008,). Pure stem bromelain is stable when stored at $-20^{\circ} \mathrm{C}$ and has an optimum $\mathrm{pH}$ range of 6-8.5 for most of its substrates (casein, gelatin, synthetic peptides, etc.). The optimum temperature range for the enzyme is $50-60^{\circ} \mathrm{C}$. It is mostly activated by cysteine while hydrogen sulfide and sodium cyanide are less effective (Bencucci et al. 2011). However, heavy metals such as mercury and silver, and L-trans-epoxysuccinylleucylamido (4-guanidino) butane [also known as E-64] deactivate the enzyme (Maurer, 2001,). In contrast, fruit bromelain (E.C. 3.4.22.33) is genetically distinct from stem bromelain. It has higher proteolytic activity and broader specificity for substrates compared to stem bromelain (Maurer, 2001,). Bromelain has been widely used in meat tenderization and as a dietary supplement (Ravindra et al. 2008,), as well as food processing and 
baking industry (Lyons, 1982,). Bromelain also has greater therapeutic applications. It was firstly introduced as a therapeutic compound in 1957 (Gregory and Kelly, 1996,). Clinical applications of bromelain includes modulation of tumor growth, third degree burns, improvement of antibiotic action, etc. (Maurer, 2001).

Response surface methodology (RSM) has been greatly used for the optimization and studying the interactions among various bioprocess parameters using a minimum number of experiments. It is a unit of statistical tools for designing experiments, constructing models, assessing the effects of factors, and exploring optimum conditions of factors under study for desirable responses (de-Coninck et al. 2000,). The technique has been widely utilized in many areas of biotechnological processes such as in the production of enzymes and antibiotics (de-Coninck et al. 2000).

Escherichia coli has been continuously utilized for the high-level production of recombinant proteins (Benucci, 2011). This is because of its availability and fully understood genetics. In addition, $E$. coli has the capacity to grow rapidly at high cell concentrations using cheap media (Manderson et al. 2006). Recombinant proteins expression in $E$. coli often leads to the formation of insoluble or nonfunctional proteins (Sørensen and Mortensen, 2005,). The recovery of soluble protein from the inclusion bodies often yields less active enzyme and can significantly raise the cost of bioseparation (Lilie et al. 1998,). Consequently, it is vital to express the protein in a biologically active form. Many factors affecting culture growth rates are being manipulated in order to reduce inclusion bodies formation. These include lowering of culture temperature (Hoffmann and Rinas, 2001,), using early induction time of expression (Lim et al. 2000,), nutrient and oxygen restriction (Ryan et al. 1989,), increasing post-induction time, and regulating the inducer concentration (Manderson et al. 2006).

Considering the significance of assessing the effects of process variables on the recombinant proteins expression, the current research work was geared towards the evaluations of the effects of cultivation conditions (postinduction temperature, inducer concentration and postinduction period) on the production of soluble and active recombinant pineapple stem bromelain in $E$. coli.

\section{Materials and methods Chemicals}

L-Cysteine, L-arabinose and casein were purchased from Sigma Chemicals Company (USA). Luria Bertani (LB) growth media used was a product of Merck, Germany. All other chemicals used were of analytical grade.

\section{Strain and plasmid}

The Escherichia coli BL21-AI strain (Invitrogen, USA) harboring pineapple stem bromelain gene used in this study was described in our earlier study (Amid et al. 2011). Briefly, the gene encoding pineapple stem bromelain was initially cloned into pENTR/TEV/D-TOPO before being sub-cloned into the expression vector pDEST17 (Invitrogen, USA). The expression vector containing recombinant bromelain gene was then transformed in E. coli BL21-AI competent cells.

\section{Screening of cultivation conditions}

The screening experiments were conducted in $250 \mathrm{~mL}$ shake flasks. Transformant cells were grown overnight in $5 \mathrm{~mL} \mathrm{LB}$ media containing $100 \mu \mathrm{g} / \mathrm{mL}$ ampicillin until the $\mathrm{OD}_{600 \mathrm{~nm}}$ reached 0.6-1.0 (Amid et al. 2011). One milliliter of the culture was then diluted 50 fold in a fresh $\mathrm{LB}$ media and then cultivated (at $37^{\circ} \mathrm{C}, 250 \mathrm{rpm}$ ) up to $\mathrm{OD}_{600 \mathrm{~nm}}$ 0.4-0.8, cell densities. In order to study the effects of post-induction temperature, the cultivation temperature was adjusted to $20-37^{\circ} \mathrm{C}$ (Table 1 ) and then $\mathrm{L}$-arabinose was added to a final concentration of $0.2 \%$ $(\mathrm{w} / \mathrm{v})$ to each flask. For the inducer trial, the growth culture was adjusted to $37^{\circ} \mathrm{C}$ and then induced with 0.1 $0.3 \%(\mathrm{w} / \mathrm{v}) \mathrm{L}$-arabinose. Post-induction period for cell harvest was studied at a range of $2-10 \mathrm{hr}$ as presented in Table 1. All the experiments were conducted in triplicates.

\section{Response surface methodology (RSM)}

RSM was employed to optimize the screened induction conditions that enhanced the recombinant bromelain production. Face centered central composite design (FCCCD) developed by the Design Expert software (Version 6.0.8, Stat-Ease Inc., Minneapolis, USA), was used to optimize the three significant cultivation conditions: post-induction temperature, inducer concentration and post-induction period. A set of 20 experimental runs with six replicated center points were generated. Three different levels, low $(-1)$, medium $(0)$ and high $(+1)$ were used to study the independent variables. The experimental design used for the study is presented in Table 2. All the experiments were carried out in triplicates and the average of bromelain activity was considered as the response (Y). The following second-order

\section{Table 1 Induction parameters screened for bromelain} production in BL21-AI

\begin{tabular}{ll}
\hline Induction condition $^{\mathbf{1}}$ & Range $^{\mathbf{2}}$ \\
\hline Cell concentration (induction time) & $\mathrm{OD}_{600 \mathrm{~nm}}$ of $0.4-0.8$ \\
L-arabinose concentration & $0.1-0.3 \%(\mathrm{~W} / \mathrm{V})$ \\
Post-induction period (harvest time) & $2-10 \mathrm{hr}$ \\
Temperature & $20-37^{\circ} \mathrm{C}$ \\
\hline
\end{tabular}

${ }^{1}$ All the tests were carried out at $37^{\circ} \mathrm{C}, \mathrm{OD}_{600 \mathrm{~nm}}$ of $0.4,0.2 \%(\mathrm{w} / \mathrm{v}) \mathrm{L}$-arabinose and $4 \mathrm{hr}$ post- induction period (besides the specific test conditions).

${ }^{2}$ Cultivation conditions and their ranges were selected based on literature reports on recombinant protein expression. 


\begin{tabular}{|c|c|c|c|c|c|}
\hline \multirow[t]{2}{*}{ Run } & \multirow[t]{2}{*}{ Temperature, ${ }^{\circ} \mathrm{C}$} & \multirow{2}{*}{$\begin{array}{c}\text { Inducer concentration, } \\
\% \mathrm{w} / \mathrm{v}\end{array}$} & \multirow[t]{2}{*}{ Post induction period, $\mathrm{hr}$} & \multicolumn{2}{|c|}{ Bromelain production $(\mathrm{U} / \mathrm{mg})$} \\
\hline & & & & Experimental & Predicted \\
\hline 1 & $25(0)$ & $0.20(0)$ & $8(0)$ & $8.90 \pm 0.08$ & 9.10 \\
\hline 2 & $20(-1)$ & $0.10(-1)$ & $6(-1)$ & $5.00 \pm 0.03$ & 4.90 \\
\hline 3 & $30(+1)$ & $0.30(+1)$ & $10(+1)$ & $4.80 \pm 0.02$ & 4.90 \\
\hline 4 & $20(-1)$ & $0.30(+1)$ & $6(-1)$ & $6.90 \pm 0.05$ & 6.90 \\
\hline 5 & $25(0)$ & $0.10(-1)$ & $8(0)$ & $8.70 \pm 0.08$ & 8.70 \\
\hline 6 & $25(0)$ & $0.20(0)$ & $8(0)$ & $9.20 \pm 0.09$ & 9.10 \\
\hline 7 & $25(0)$ & $0.20(0)$ & $10(+1)$ & $8.50 \pm 0.07$ & 8.60 \\
\hline 8 & $30(+1)$ & $0.10(-1)$ & $10(+1)$ & $8.50 \pm 0.06$ & 8.50 \\
\hline 9 & $25(0)$ & $0.20(0)$ & $8(0)$ & $9.20 \pm 0.09$ & 9.10 \\
\hline 10 & $30(+1)$ & $0.30(+1)$ & $6(-1)$ & $7.20 \pm 0.05$ & 7.20 \\
\hline 11 & $25(0)$ & $0.20(0)$ & $8(0)$ & $8.90 \pm 0.08$ & 9.10 \\
\hline 12 & $25(0)$ & $0.20(0)$ & $6(-1)$ & $8.60 \pm 0.06$ & 8.50 \\
\hline 13 & $20(-1)$ & $0.30(+1)$ & $10(+1)$ & $7.30 \pm 0.04$ & 7.10 \\
\hline 14 & $25(0)$ & $0.20(0)$ & $8(0)$ & $8.90 \pm 0.07$ & 9.10 \\
\hline 15 & $20(-1)$ & $0.10(-1)$ & $10(+1)$ & $7.40 \pm 0.05$ & 7.40 \\
\hline 16 & $25(0)$ & $0.30(+1)$ & $8(0)$ & $7.90 \pm 0.06$ & 7.90 \\
\hline 17 & $25(0)$ & $0.20(0)$ & $8(0)$ & $9.20 \pm 0.08$ & 9.10 \\
\hline 18 & $30(+1)$ & $0.10(-1)$ & $6(-1)$ & $8.40 \pm 0.05$ & 8.50 \\
\hline 19 & $20(-1)$ & $0.02(0)$ & $8(0)$ & $7.60 \pm 0.05$ & 7.90 \\
\hline 20 & $30(+1)$ & $0.20(0)$ & $8(0)$ & $8.80 \pm 0.07$ & 8.60 \\
\hline
\end{tabular}

polynomial equation explains the relationship between dependent and independent variables:

$$
Y=\beta_{0}+\beta_{1} X_{1}+\beta_{2} X_{2}+\beta_{3} X_{3}+\beta_{12} X_{1} X_{2}+\beta_{13} X_{I} X_{3}+\beta_{23} X_{2} X_{3}+\beta_{11} X_{1}^{2}+\beta_{22} X_{2}^{2}+\beta_{33} X_{3}^{2}
$$

where $\mathrm{Y}$ is the dependent variable (bromelain production); $X_{1}, X_{2}$ and $X_{3}$ are independent variables (temperature, inducer concentration and time, respectively); $\beta_{0}$ is an intercept term; $\beta_{1}, \beta_{2}$ and $\beta_{3}$ are linear coefficients; $\beta_{12}, \beta_{13}$ and $\beta_{23}$ are the interaction coefficients; and $\beta_{11}$, $\beta_{22}$ and $\beta_{33}$ are the quadratic coefficients. The evaluation of the analysis of variance (ANOVA) was determined by conducting the statistical analysis of the model. In order to depict the relationship between the responses and the experimental levels of each of the variables under study, the fitted polynomial equation was expressed in the form of contour and response surface plots.

\section{Validation of the experimental model}

The statistical model was validated with respect to the entire three variables within the design space. A set of six experimental combinations, selected as predicted by the point prediction feature of the Design Expert software, were utilized to study the maximum bromelain production under defined conditions. All the experiments were carried out in triplicates and the results were then compared with the predicted values.
Recombinant bromelain production with face centered central composite design (FCCCD)

The effects of varying post-induction temperature, L-arabinose inducer concentration and post-induction period on bromelain production were evaluated in shake flask experiments. As described earlier, all cultures were grown at $37^{\circ} \mathrm{C}$ and $250 \mathrm{rpm}$ agitation until $\mathrm{OD}_{600 \mathrm{~nm}}$ reaches 0.6 . This was followed by adding varying L-arabinose concentrations $(0.1-0.3 \%)$ to the cultures that were adjusted at different temperatures $\left(20-30^{\circ} \mathrm{C}\right)$. The cell cultures were allowed to continue growing for $6 \mathrm{hr}, 8 \mathrm{hr}$ and $10 \mathrm{hr}$ (according to the experimental design) after induction and adjustment of growing temperature. Cells were harvested from the spent media by centrifugation $(6000 \times g)$ at $4^{\circ} \mathrm{C}$, for $20 \mathrm{~min}$ and stored at $-20^{\circ} \mathrm{C}$ for further use (Ismail and Amid, 2008a,; Ismail and Amid, 2008b). All experiments were performed in triplicates.

\section{Enzyme recovery and purification}

The harvested cells were subjected to sonication (sonicator, $150 \mathrm{v} / \mathrm{t}$ model, Biologics, Inc. USA) on ice using 6-10 sec burst, with $10 \mathrm{sec}$ interval at high amplitude. This was followed by centrifugation $(13000 \times g)$ at $4{ }^{\circ} \mathrm{C}$, for $30 \mathrm{~min}$ and the supernatant was collected and purified by AKTA purifier FPLC system (GE Healthcare Bio-Sciences, USA). Purification of recombinant bromelain was conducted in accordance to the manufacturer's 
instructions. A glass column for chromatography (4.6 $\mathrm{mm} \times 100 \mathrm{~mm}$, Life Technologies, California) was filled with $1 \mathrm{~mL}$ of Ni-NTA His•Bind resin (Novagen, Germany). The FPLC system was set at flow rate of $1 \mathrm{~mL} /$ min. Washing step was achieved by using wash buffer (50 mM NaH $\mathrm{PO}_{4}, 300 \mathrm{mM} \mathrm{NaCl}, 20 \mathrm{mM}$ imidazole, $\mathrm{pH}$ 8) while purified recombinant bromelain was eluted using elution buffer $\left(50 \mathrm{mM} \mathrm{NaH} \mathrm{PO}_{4}, 300 \mathrm{mM} \mathrm{NaCl}\right.$, 500 mM imidazole, $\mathrm{pH}$ 8).

\section{SDS-PAGE}

After each step of enzyme recovery and purification, the protein fractions were tested by SDS-PAGE in 12.5\% polyacrylamide gels as described earlier (Amid et al. 2011,). Visualization was conducted by staining with Coomassie Brilliant blue (Laemmli, 1970).

\section{Determination of enzyme activity}

The reaction mixture contained $0.1 \mathrm{~mL}$ of purified recombinant bromelain and $1.1 \mathrm{~mL}$ of $1 \%$ casein in 0.1 $\mathrm{M}$ Tris- $\mathrm{HCl}$ buffer ( $\mathrm{pH} \mathrm{8.0)}$ with $20 \mathrm{mM}$ cysteine (final concentration). The reaction was conducted at $37^{\circ} \mathrm{C}$ for $20 \mathrm{~min}$. The reaction was stopped by adding $1.8 \mathrm{~mL}$ of $5 \%(\mathrm{w} / \mathrm{v})$ trichloroacetic acid (TCA). This was followed by centrifugation at $10000 \times g$ for $15 \mathrm{~min}$ and the absorbance of the supernatant was measured at $280 \mathrm{~nm}$. One unit (U) of the enzyme was defined as the amount of protease that produces an increment of one absorbance unit per minute in the assay conditions (Bruno et al. 2003).

\section{Results}

Screening of culture growth induction conditions using one-factor-at-a-time (OFAT) method

In order to explore the possibility of improving the expression level of recombinant bromelain, several onefactor experiments were employed to investigate the effects of various cultivation conditions on recombinant bromelain production. The tested variables included cell concentration, post-induction temperature, inducer concentration and post-induction period for cell harvest. All the experiments were carried out in triplicates.

\section{Cell concentration (induction time)}

Induction serves as a turning point between cell growth and recombinant protein synthesis in $E$. coli (Xu et al. 2006). The cloning and expression system employed requires the addition of L-arabinose to trigger the transcription of foreign gene in the plasmid and initiate the translation of recombinant protein. This leads to several changes in the metabolism of host cells. The activity of recombinant bromelain at different induction time varies widely from 0.6-1.2 U/mg (Figure 1). The maximum yield of the protein was obtained when the induction was carried out at approximate $\mathrm{OD}_{600 \mathrm{~nm}}$ of 0.6 . It can

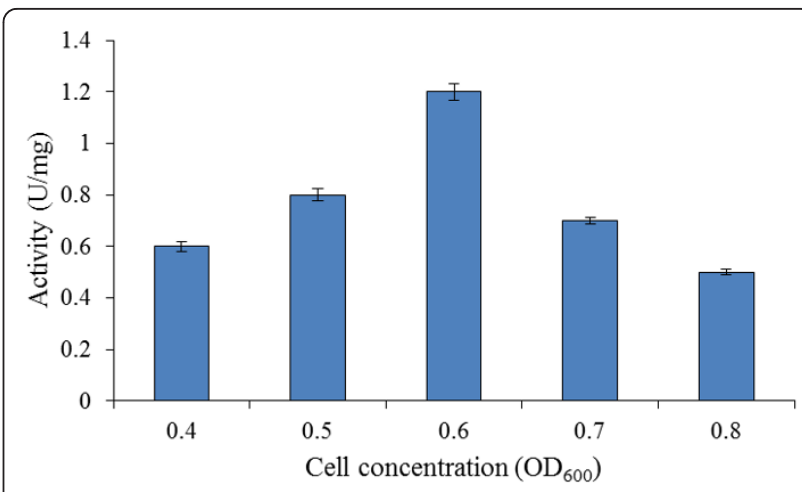

Figure 1 Effects of different cell concentrations on bromelain activity by BL21-AI. Tests were carried out at varying cell concentrations $\left(\mathrm{OD}_{600 \mathrm{~nm}}\right.$ of $\left.0.4-0.8\right)$, while temperature of $37^{\circ} \mathrm{C}$, $0.2 \%(\mathrm{w} / \mathrm{V}) \mathrm{L}$-arabinose and $4 \mathrm{hr}$ post-induction period were kept constant.

be seen from Figure 1 that early induction has great effects on the bromelain production.

\section{Post-induction temperature}

The effects of post-induction temperature on recombinant bromelain production are shown in Figure 2. The results obtained indicated that the target protein achieved highest activity value of $1.70 \pm 0.03 \mathrm{U} / \mathrm{mg}$ at a temperature of $25^{\circ} \mathrm{C}$. The bromelain activity increased as the post-induction temperature was raised from 20 to $25^{\circ} \mathrm{C}$. However, the activity of the protein declined as the post-induction temperature was further raised from $30^{\circ} \mathrm{C}$ to the optimal growth temperature of $37^{\circ} \mathrm{C}$.

\section{Effects of L-arabinose concentration}

As the expression vector used in this study had T7 araBAD promoter, the final L- arabinose concentration should be optimized. This is necessary since araBAD is a highly regulated promoter in which its expression level is essentially modulated by L-arabinose

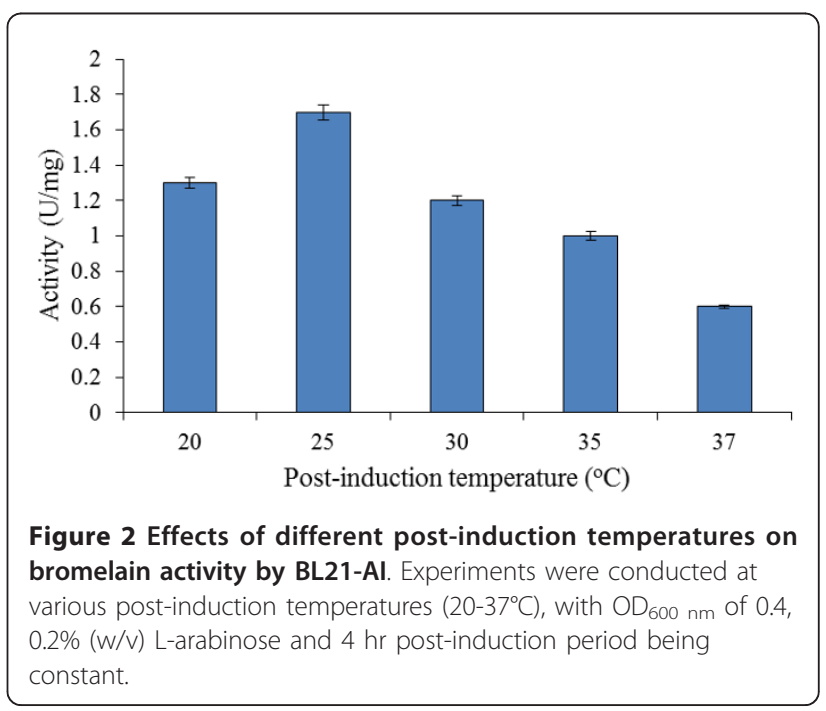




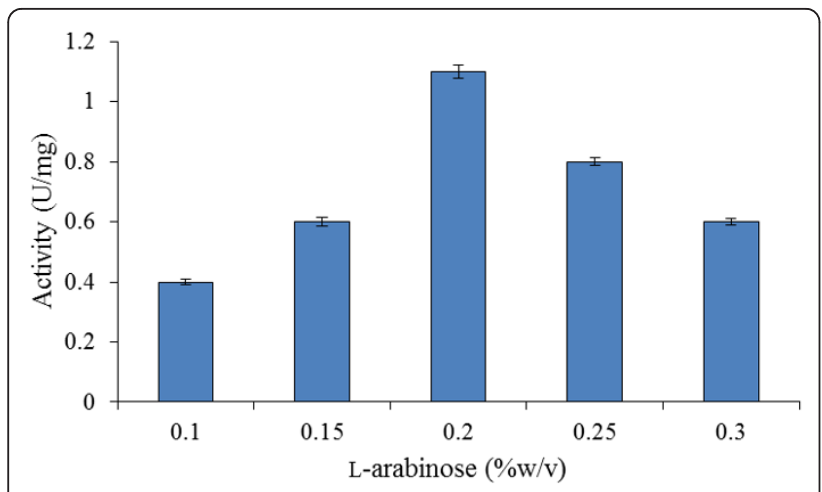

Figure 3 Effects of different inducer concentrations on bromelain activity by BL21-AI. Tests were carried out at varying L-arabinose concentrations (0.1-0.3\% w/v) while $\mathrm{OD}_{600} \mathrm{~nm}$ of $0.4,37^{\circ}$ $\mathrm{C}$ and $4 \mathrm{hr}$ post-induction period were kept constant.

concentration (Guzman et al. 1995). It can be inferred from Figure 3 that the concentration of the inducer had a strong effect on the specific activity of recombinant bromelain. An increase in recombinant bromelain production was seen by increasing the L-arabinose concentrations from $0.1-0.2 \%(\mathrm{w} / \mathrm{v})$. The maximum recombinant protein production was achieved at inducer concentration of $0.2 \%(\mathrm{w} / \mathrm{v})$. The specific activity of bromelain decreased afterwards as higher levels of L-arabinose retarded the rate of cells' growth.

\section{Post-induction period for cell harvest}

The recombinant protein synthesis began extensively after the addition of L-arabinose into the growth culture. The production of target bromelain was found to be proportional to the expression time up to $8 \mathrm{hr}$ (Figure 4). The maximum bromelain activity of $1.40 \mathrm{U} / \mathrm{mg}$ \pm 0.03 was attained after $8 \mathrm{hr}$ post-induction period. After $8 \mathrm{hr}$, the production rate of recombinant bromelain started to regress. It could be observed that the activity of recombinant bromelain after L-arabinose

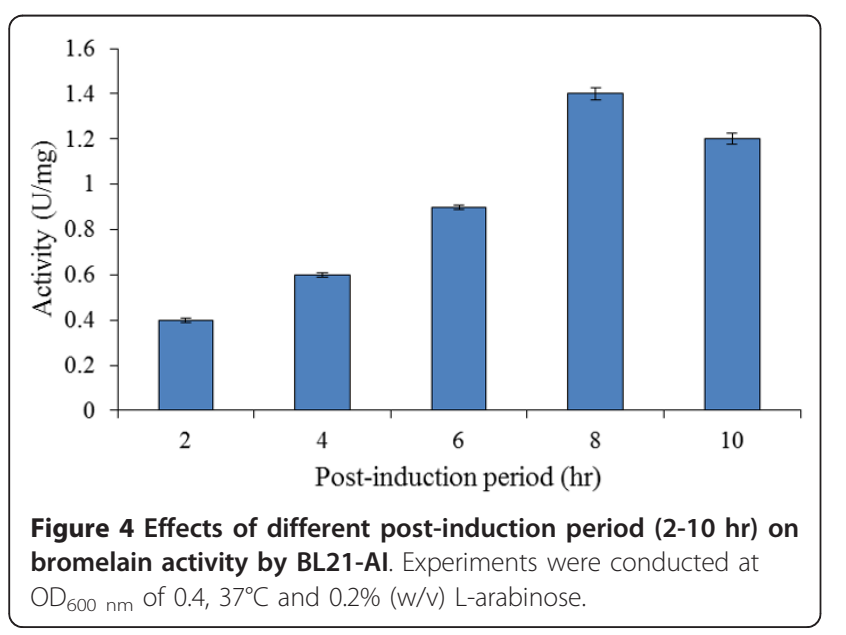

induction changed with expression conditions, especially the post-induction period.

\section{Optimization by Response Surface Methodology (RSM)}

The use of statistically based experimental design is a vital tool in optimizing the induction conditions that may bring several fold increment in bromelain production. RSM provides several important advantages such as the factor effects, determination of the optimum values as well as development of a system model with less experimental requirements (Salihu et al. 2011). It could be seen from the results in Table 2 that the highest amount of bromelain produced (8.9-9.2 U/mg) was obtained in the runs representing the center points (runs 1, 6, 9, 11, 14 and 17) while the lowest value was observed in run $3(4.8 \pm 0.02 \mathrm{U} / \mathrm{mg})$. A second order regression equation showed the dependence of bromelain activity on the growth culture induction conditions. Multiple regression analysis of the experimental data provided the parameters of the equation. A secondorder polynomial equation was used to express the empirical relationship between the response and the significant variables:

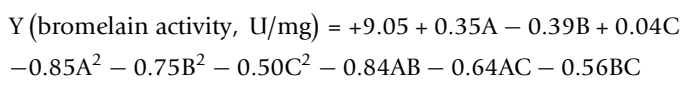

where the response $(\mathrm{Y})$ is the bromelain production, while $\mathrm{A}, \mathrm{B}$ and $\mathrm{C}$ are the temperature, inducer concentration and post-induction period, respectively.

The analysis of variance (ANOVA) tested using Fisher's statistical analysis, was used to verify the adequacy of the model. The results are shown in Table 3 . The model F-value of 99.32 with $p$-value of 0.0001 implied that the model was significant. As lack of fit is not significant, it clearly implies that the obtained experimental responses adequately fit with the model. The predicted $R^{2}$ value of 0.9266 is found to be in reasonable

Table 3 Analysis of Variance of quadratic model for bromelain production

\begin{tabular}{lccc}
\hline Source & Sum of squares & F-value & P-value \\
\hline Model & 30.67 & 99.32 & 0.0001 \\
Post-induction temperature, A & 1.22 & 35.71 & 0.0001 \\
Inducer concentration, B & 1.52 & 44.34 & 0.0001 \\
Post-induction period, C & 0.016 & 0.47 & 0.5102 \\
A $^{2}$ & 2.01 & 58.54 & 0.0001 \\
$\mathrm{~B}^{2}$ & 1.57 & 45.64 & 0.0001 \\
$\mathrm{C}^{2}$ & 0.70 & 20.41 & 0.0001 \\
$\mathrm{AB}$ & 5.61 & 163.56 & 0.0001 \\
$\mathrm{AC}$ & 3.25 & 94.77 & 0.0001 \\
$\mathrm{BC}$ & 2.53 & 73.78 & 0.0001 \\
Lack of fit & 0.21 & 1.54 & 0.3233 \\
\hline $\mathrm{R}^{2}=0.9889$, adjusted $\mathrm{R}^{2}=0.9790$, C.V. $=2.32$, adequate precision $=31.695$
\end{tabular}


agreement with the adjusted $R^{2}$ value of 0.9790 and thus, suggesting that the model is well fit. In addition, the adequate precision value of 31.695 for recombinant bromelain production implies that the model can be used to navigate the design space. In this model, a lower value of 2.32 for the coefficient of variation $(\mathrm{CV})$, suggested a good precision and reliability of the experiment. The coefficient values of the regression equation are shown in Table 3.

In order to understand the interactions of induction conditions and to find the optimum conditions required for maximum bromelain production, the 3-D response surface curves were plotted. Response surface contour plots and three dimensional graphs provide clear information on the relationship between the response and experimental levels of each variable. They also explain the type of interaction existing between the test variables and help to obtain the optimum conditions (Haaland, 1989). Three response surfaces (Figure 5) had been shown by considering all the possible combinations. The 3D plots shown in Figure 5 are based on the function of induction conditions of the two variables with the other one being kept at its optimum level. The elliptical nature of the contour plot indicates the significance of the interactions between the corresponding variables. Figure 5 a shows the interaction between post induction temperature and inducer concentration. It can be seen that maximum bromelain production was attained at induction temperature of $25^{\circ} \mathrm{C}$ and $\mathrm{L}$-arabinose concentration of $0.2 \%(\mathrm{w} / \mathrm{v})$.

Moreover, Figure $5 \mathrm{~b}$ represents the 3D plot corresponding to temperature and post-induction period. The plot exhibited an elliptical contour that suggests both optimum operating conditions and the interaction effects between the two factors are significant. Figure $5 \mathrm{~b}$ shows that maximum bromelain production was attained at $8 \mathrm{hr}$ post-induction period.

Similarly, in the case of inducer concentration and post induction time (Figure 5c); the response plot was elliptical signifying interaction between them with optimum production of the enzyme. Consequently, the optimized cultivation conditions synergistically favor higher production of bromelain.

In order to ascertain the feasibility of the application of the optimal conditions earlier generated, a validation experiment was conducted as presented in Table 4. It could be seen that some of the experimental values are slightly higher than the predicted ones. This could possibly be explained based on the experimental conditions used in the border zone of the technological space considered in FCCCD. The validation of predicted bromelain production yielded $9.6 \pm 0.02 \mathrm{U} / \mathrm{mg}$ of the enzyme under optimized cultivation conditions. Hence, 5.65-fold raise in overall bromelain production was achieved as compared to non-optimized conditions (Figure 2, in which maximum bromelain activity was $1.7 \pm 0.03 \mathrm{U} /$ $\mathrm{mg})$.

\section{Discussion}

There are several strategies that are being employed to improve culture cultivation conditions for expressing soluble recombinant proteins in E. coli. The screening of experimental conditions for the improvement of enzyme expression coupled with the RSM experimental design serve as vital tool for analyzing the influence of cultivation conditions on the expression of recombinant bromelain. The design had proved to be effective in determining the important induction conditions that have significant effect on recombinant bromelain production in E. coli BL21-AI. Using face centered central composite design (FCCCD), the optimum induction conditions for high bromelain activity were induction temperature $\left(27^{\circ} \mathrm{C}\right)$, L-arabinose concentration $(0.15 \%$ $\mathrm{w} / \mathrm{v}$ ) and post-induction period of $8 \mathrm{hr}$. The results presented in this research for the analysis of cultivation conditions for the expression of recombinant bromelain corroborate the applicability of experimental design to the field of molecular biology.

This study had found out that the studied parameters had exerted great effects on the production of recombinant bromelain at higher level. Lower cultivation temperature of $25^{\circ} \mathrm{C}$ under optimized conditions (Figure 5a and $5 \mathrm{~b}$ ), had effectively improved the bromelain production. It is an established fact that expression of soluble recombinant enzymes is highly favored by lower growth temperature. During expression of recombinant proteins that have tendency to form insoluble aggregates in $E$. coli, decreasing the post-induction temperature has been shown to significantly reduce protein aggregation (MacDonald et al. 2003,). In addition, in T7 expression system (used in this study), a large number of recombinant proteins often precipitate when expressed at $37^{\circ} \mathrm{C}$, but tend to be soluble when induction temperature is lowered to $15-25^{\circ} \mathrm{C}$ (Vera et al. 2007,). This is because slower rates of protein production allow the newly transcribed recombinant proteins sufficient time to fold properly. Hence, lower temperatures during induction in such expression system should be used as the default (Vera et al. 2007,). This is also supported by the findings of Schein and Noteborn (1988) in which the productions of soluble fraction of the recombinant proteins expressed in various $E$. coli strains were increased at culture temperatures in the range of $20-30^{\circ} \mathrm{C}$.

Moreover, temperature also affects the stability of plasmid in recombinant E. coli cultures (Shin et al. 1997, \&Wang et al. 2005,) and thus affects production of soluble proteins (Islam et al. 2007, \&Swalley et al. 2006,). Lower temperatures coupled with lower cell 


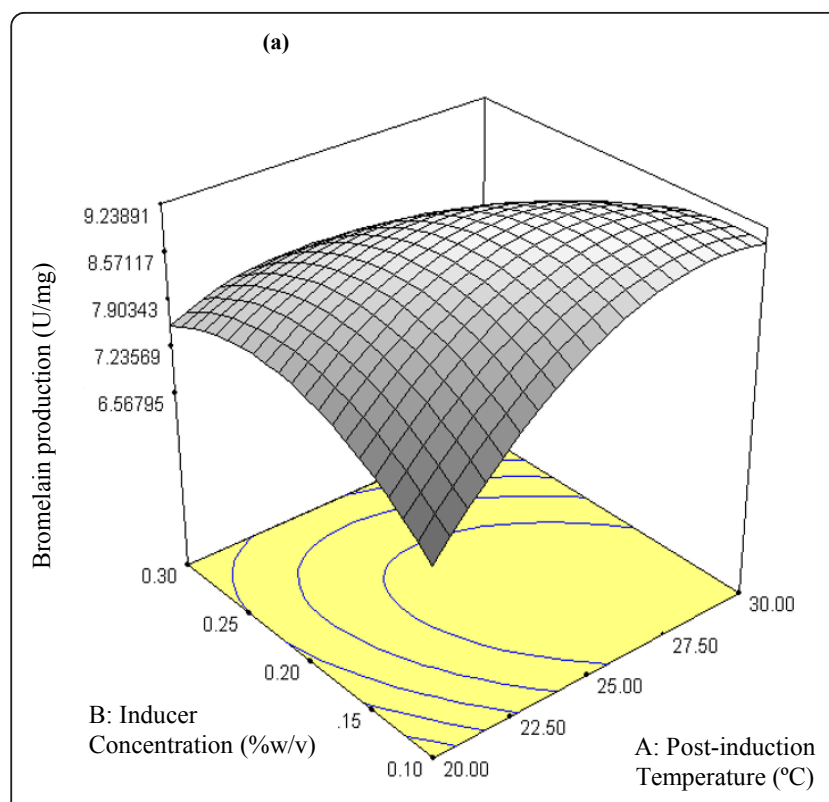

(b)

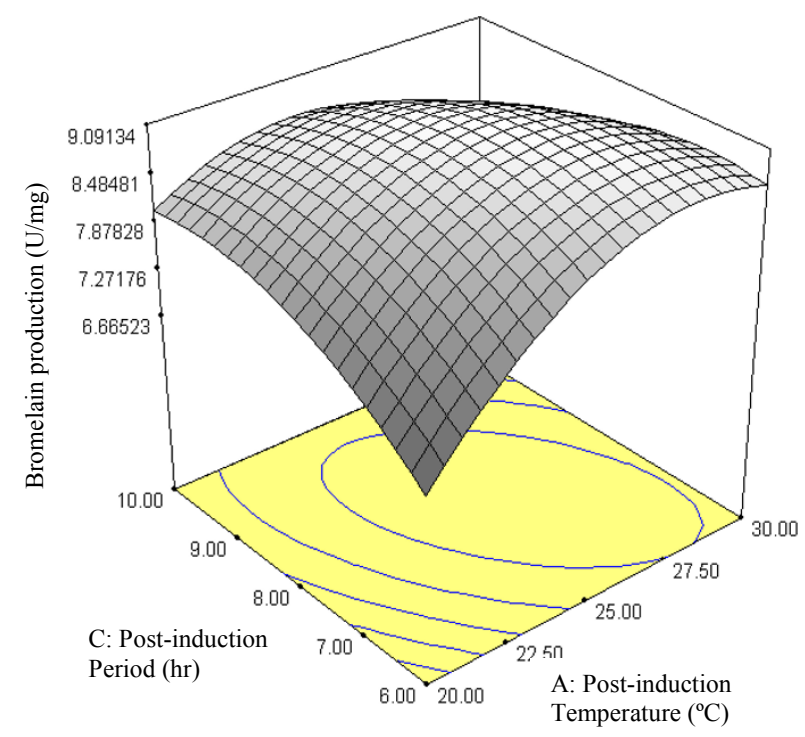

(c)

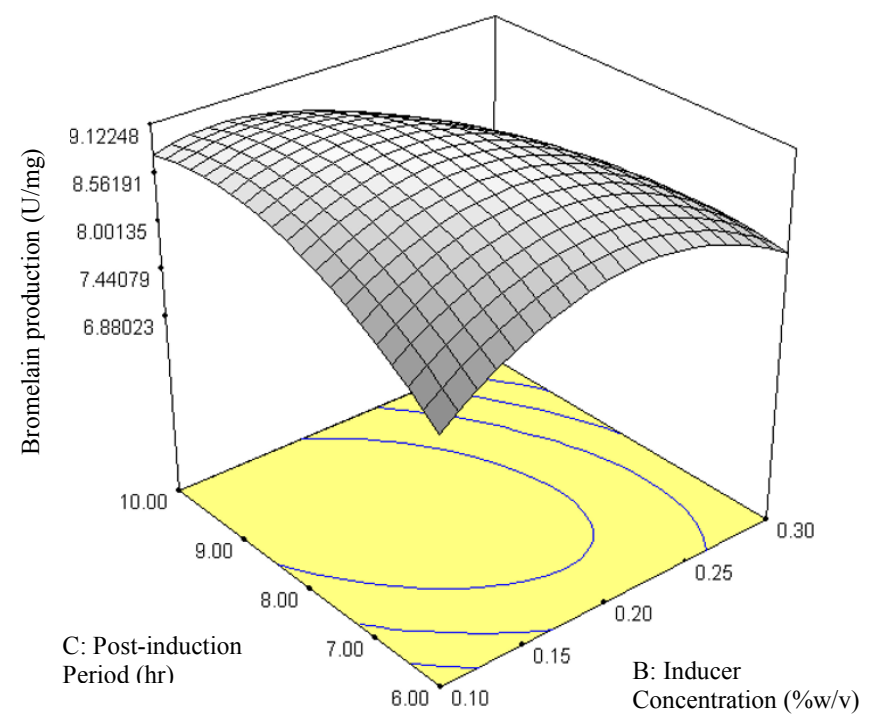

Figure 5 The 3D response surface curves of the combined effects of post-induction temperature, inducer concentration and postinduction period on bromelain production. (a) Temperature and inducer concentration at a fixed level of post-induction period. Tests were carried out at $\mathrm{OD}_{600 \mathrm{~nm}}$ of 0.6 with varying temperature $\left(20-30^{\circ} \mathrm{C}\right)$ and L-arabinose concentrations $(0.1-0.3 \% \mathrm{w} / \mathrm{v})$. Post-induction period of $8 \mathrm{hr}$ was used. (b) Post-induction temperature and post-induction period at fixed level of inducer concentration. Tests were carried out at $\mathrm{OD}_{600} \mathrm{~nm}$ of 0.6 with varying post-induction temperature $\left(20-30^{\circ} \mathrm{C}\right)$ and post-induction period $(2-10 \mathrm{hr})$. Inducer concentration of $0.2 \%(\mathrm{w} / \mathrm{v})$ was used $(\mathrm{c})$ Inducer concentration and post-induction period at fixed level of post-induction temperature. Tests were carried out at $\mathrm{OD}_{600 \mathrm{~nm}} \mathrm{Of} 0.6 \mathrm{with}$ varying L-arabinose concentrations $(0.1-0.3 \% \mathrm{w} / \mathrm{v})$ and post-induction period $(2-10 \mathrm{hr})$. A post-induction temperature of $25^{\circ} \mathrm{C}$ was used.

growth rates usually favor higher production of soluble protein. This is based on the type of expression system and recombinant protein involved (Urban et al. 2003,). The results from the aforementioned study (Urban et al. 2003) are in well accordance with our findings.

In this study, it was discovered that moderate concentration of $\mathrm{L}$-arabinose $(0.2 \% \mathrm{w} / \mathrm{v})$ used under the optimized conditions, has greatly contributed towards attaining higher bromelain production as shown in Figure 3, 5a and 5c. This indicated that higher levels of Larabinose decreases recombinant protein expression. In fact it has been reported that higher concentrations of $\mathrm{L}$-arabinose cause over production of recombinant protein that leads to ribosomal destruction, production of 
Table 4 Experimental model validation

\begin{tabular}{|c|c|c|c|c|c|}
\hline \multirow[t]{2}{*}{ Experiment } & \multirow{2}{*}{$\begin{array}{l}\text { Post-induction temperature } \\
\qquad\left({ }^{\circ} \mathrm{C}\right)\end{array}$} & \multirow[t]{2}{*}{ Inducer concentration $(\% \mathrm{w} / \mathrm{v})$} & \multirow{2}{*}{$\begin{array}{l}\text { Post induction period } \\
\text { (hr) }\end{array}$} & \multicolumn{2}{|c|}{ Bromelain production $(\mathrm{U} / \mathrm{mg})$} \\
\hline & & & & Experimental & Predicted \\
\hline 1 & 27 & 0.15 & 8 & $9.60 \pm 0.02$ & 9.20 \\
\hline 2 & 27 & 0.15 & 9 & $9.30 \pm 0.03$ & 9.10 \\
\hline 3 & 27 & 0.20 & 9 & $8.90 \pm 0.03$ & 8.80 \\
\hline 4 & 27 & 0.18 & 9 & $9.10 \pm 0.02$ & 9.00 \\
\hline 5 & 27 & 0.15 & 9.5 & $9.20 \pm 0.03$ & 9.00 \\
\hline 6 & 25 & 0.15 & 9 & $9.30 \pm 0.03$ & 9.10 \\
\hline
\end{tabular}

heat shock proteins and eventually cell death (Guzman et al. 1995,). Our findings are consistent with the works of Manderson et al. (2006) in which maximum recombinant aspin production was attained at L-arabinose concentration of $0.2 \%(\mathrm{w} / \mathrm{v})$ but reduced at higher inducer concentration. Aspin is an aspartyl protease inhibitor homolog which is being produced by the parasitic nematode, Trichostrongylus colubriformis (Manderson et al. 2006,). In addition, the use of partial induction to slow the rate of recombinant protein expression has been reported to enhance the formation of soluble protein (Lim et al. 2000,). More so, a significant increase was observed in the production of soluble interferon upon induction with low level of L-arabinose (Lim et al. 2000).

The optimization studies in this work were conducted at a fixed cell concentration (induction time) which was screened earlier under OFAT method. Maximum bromelain production was achieved at cell concentration of $\mathrm{OD}_{600 \mathrm{~nm}}=0.6$ as shown in Figure 1. The effects of induction time depend on the specific expression case (Manderson et al. 2006,). In some cases, early induction increases soluble protein production of some recombinant proteins by limiting the culture growth rate (Delisa et al. 2001,). This was supported by the findings of Lim and Jung (1998), in which a five-fold improvement in soluble interferon production was attained by induction in early logarithmic phase. However, Akesson et al. (2001) had reported higher levels of recombinant protein expression when induced in the late exponential growth phase.

The effect of post-induction period on bromelain production was found to be at its peak after $8 \mathrm{hr}$ as shown in Figure 4, 5b and 5c. Bromelain production started to reduce beyond this period. Thus, cultivation at lower temperatures and moderately longer post-induction period could significantly enhance the expression of the recombinant protein in comparison with the standard $E$. coli growth temperature of $37^{\circ} \mathrm{C}$. This could be explained by the fact that the solubility and refolded conformation of recombinant enzymes were greatly enhanced by cultivation conditions and certain post- translational time was needed to get a mature protein with high enzymatic activity (Xu et al. 2007,). It is vital to control the time and extent of plasmid gene expression as the recombinant protein can effectively inhibit host cell growth, presumably due to its toxicity (Shin et al. 1997,). Moreover, the metabolic load exerted on the host cells through heterologous gene expression may lead to retardation of growth (Manderson et al. 2006).

\section{End notes}

1. All the tests were carried out at $37^{\circ} \mathrm{C}, \mathrm{OD}_{600 \mathrm{~nm}}$ of $0.4,0.2 \%(\mathrm{w} / \mathrm{v})$ L-arabinose and $4 \mathrm{hr}$ post-induction period (besides the specific tested conditions).

2. Cultivation conditions and their ranges were selected based on literature reports on recombinant proteins expression.

\section{Acknowledgements}

The authors are most grateful to the Department of Biotechnology Engineering, IIUM, for providing all the required laboratory facilities to successfully conduct the research work as well as financial assistance from the Ministry of Higher Education, Malaysia (FRGS grant no.11-04-0162) to Azura Amid and Hamzah M. Salleh.

\section{Author details}

'Bioprocess and Molecular Engineering Research Unit, Department of Biotechnology Engineering, Faculty of Engineering, International Islamic University Malaysia, P.O. Box 10, 50728, Kuala Lumpur, Malaysia ${ }^{2}$ Department of Biochemistry, Faculty of Science, Bayero University, Kano. P.M.B. 3011, Kano, Nigeria

\section{Competing interests}

The authors declare that they have no competing interests.

Received: 21 November 2011 Accepted: 15 February 2012 Published: 15 February 2012

\section{References}

Akesson M, Hagander P, Axelsson J (2001) Avoiding acetate accumulation in Escherichia coli cultures using feedback control of glucose feeding. Biotechnol Bioeng 73:223-30. doi:10.1002/bit.1054.

Amid A, Ismail N, Yusof F, Salleh HM (2011) Expression, purification and characterization of a recombinant stem bromelain from Ananas comosus. Process Biochem 46:2232-2239. doi:10.1016/j.procbio.2011.08.018.

Bencucci I, Liburdi K, Garzillo A, Maria V, Esti M (2011) Bromelain from pineapple stem in alcoholic-acid buffers for wine application. Food Chem 124(4):1349-1353. doi:10.1016/j.foodchem.2010.07.087. 
Bitange NT, Zhang W, Ying X, Wenbin Z (2008) Therapeutic application of pineapple protease (bromelain): A review. Pakst J of Nutr 7(4):513-520. doi:10.3923/pjn.2008.513.520

Bruno MA, Pardo MF, Caffini NO, Lo'pez LMI (2003) Hieronymain I, a new cysteine peptidase isolated from unripe fruits of Bromelia hieronymi Mez (Bromeliaceae). J Protein Chem 22:127-134. doi:10.1023/A:1023418812832.

de Coninck J, Bouquelet S, Dumortier V, Duy F, Verdier-Denantes I (2000) Industrial media and fermentation processes for improved growth and protease production by Tetrahymena thermophila. J Ind Microbiol Biotech 24:285-290. doi:10.1038/sj.jim.2900826.

DeLisa MP, Chae HJ, Weigand WA, Valdes JJ, Rao G, Bentley WE (2001) Generic model control of induced protein expression in high cell density cultivation of Escherichia coli using on-line GFP-fusion monitoring. Bioproc Biosys Eng 24:83-91. doi:10.1007/s004490100229.

Guzman LM, Belin D, Carson MJ, Beckwith J (1995) Tight regulation, modulation, and high-level expression by vectors containing the arabinose PBAD promoter. J Bacteriol 177:4121-30

Haaland PD (1989) Separating signals from the noise. Experimental design in biotechnology. Marcel Dekker, New York

Hoffmann F, Rinas U (2001) Plasmid amplification in Escherichia coli after temperature up shift is impaired by induction of recombinant protein synthesis. Biotechnol Lett 23:1819-25. doi:10.1023/A:1012718200638.

Illanes A (2008) Enzyme Biocatalysis: Principle and application. Springer Science and Business Media, Brazil

Islam RS, Tisi D, Levy MS, Lye GJ (2007) Framework for the rapid optimization of soluble protein expression in Escherichia coli combining microscale experiments and statistical experimental design. Biotechnol Prog 23:785-793

Ismail N, Amid A (2008) Fast and reliable cloning method for bromelain gene from pineapple (Ananas comosus) stem. Abstract of International Conference on Science \& Technology: Applications in Industry \& Education, Kuala Lumpur

Ismail N, Amid A (2008) Molecular cloning, insertion and transcription confirmation and expression study of bromelain gene from Ananas comosus. Abstract of the Conference on International Graduate on Engineering and Science (IGCES'08), Kuala Lumpur

Kelly GS (1996) Bromelain: A literature review and discussion of its therapeutic applications. Alt Med Rev 1(4):243-257

Laemmli U (1970) Cleavage of structural proteins during the assembly of the head of bacteriophage T4. Nature 237:680-685

Lilie H, Schwarz E, Rudolph R (1998) Advances in refolding of proteins produced in E. coli. Curr Opin Biotechnol 9:497-501. doi:10.1016/50958-1669(98)80035-9.

Lim HK, Jung KH (1998) Improvement of heterologous protein productivity Escherichia coli under control of the PL promoter. Biotechnol Prog 14:548-53. doi:10.1021/bp980059y.

Lim HK, Jung KH, Park DH, Chung SI (2000) Production characteristics of interferon-a using an I-arabinose promoter system in a high-cell-density culture. Appl Microbiol Biotechnol 53:201-28. doi:10.1007/s002530050009.

Lucia F, Tomas GV (2010) Native and Biotechnologically engineered Plant Proteases with Industrial applications. J Food Bioprocess Technol 4:1066-1088

Lyons TP (1982) Proteinase enzymes relevant to the baking industry. Biochemical Society Transactions 10(4):287-290

Maurer HR (2001) Bromelain: Biochemistry, Pharmacology and Medical Uses. Cell Mol life Sci 58:1234-1245. doi:10.1007/PL00000936.

Manderson D, Dempster R, Chisti Y (2006) Production of an active recombinant Aspin antigen in Escherichia coli for identifying animals resistant to nematode infection. Enzyme and Microbial Technol 38:591-598. doi:10.1016/j. enzmictec.2005.03.029

MacDonald LM, Armson A, Thompson RCA, Reynoldson JA (2003) Characterization of factors favoring the expression of soluble protozoan tubulin proteins in Escherichia coli. Protein Express Pur 29:117-22. doi:10.1016/S1046-5928(03)00006-8.

Paul C (2004) Protein purification Protocols. Human press, Totowa, New Jersey

Ravindra BB, Rastogi NK, Raghavarao KS (2008) Liquid-liquid extraction of bromelain and polyphenol oxidase using aqueous two-phase system. Chem Engin Process 47:83-89. doi:10.1016/j.cep.2007.08.006.

Ryan W, Parulekar SJ, Stark BC (1989) Expression of B-lactamase by recombinant Escherichia coli strains containing plasmids of different sizes-effect of $\mathrm{pH}$, phosphate, dissolved oxygen. Biotechnol Bioeng 34:309-331. doi:10.1002/ bit.260340306.
Salihu A, Alam MZ, AbdulKarim MI, Salleh MH (2011) Optimization of lipase production by Candida cylindracea in palm oil mill effluent based medium using statistical experimental design. Journal of Molecular Catalysis B: Enzymatic 69:66-73. doi:10.1016/j.molcatb.2010.12.012.

Schein CH, Noteborn MHM (1988) Formation of soluble recombinant proteins in Escherichia coli is favoured by lower growth temperature. Biotechnol 6:291-4. doi:10.1038/nbt0388-291.

Shin CS, Hong MS, Bae CS, Lee J (1997) Enhanced production of human mini proinsulin in fed-batch cultures at high cell density of Escherichia coli BL21 (DE3)[pET-3aT2M2]. Biotechnol Prog 13:249-257. doi:10.1021/bp970018m.

Sørensen HP, Mortensen KK (2005) Soluble expression of recombinant proteins in the cytoplasm of Escherichia coli. Microbial Cell Factories 4(1):1-8. doi:10.1186/1475-2859-4-1.

Swalley SE, Fulghum JR, Chambers SP (2006) Screening factors effecting a response in soluble protein expression: formalized approach using design of experiments. Anal Biochem 351:122-127. doi:10.1016/j.ab.2005.11.046.

Urban A, Ansmant l, Motorin Y (2003) Optimisation of expression and purification of the recombinant Yol066 (Rib2) protein from Saccharomyces cerevisiae. J Chromatogr B 786:187-195. doi:10.1016/51570-0232(02)00742-0.

Vera A, Gonzalez-Montalban N, Aris A, Villaverde A (2007) The conformational quality of insoluble recombinant proteins is enhanced at low growth temperatures. Biotechnol Bioeng 96:1101-1106. doi:10.1002/bit.21218.

Wang Y, Jing C, Yang B, Mainda G, Dong M, Xu A (2005) Production of a new sea anemone neurotoxin by recombinant Escherichia coli: optimization of culture conditions using response surface methodology. Process Biochem 40:2721-2728. doi:10.1016/.jprocbio.2004.12.024

Xu Z, Jing K, Liu Y, Cen P (2007) High-level expression of recombinant glucose dehydrogenase and its application in NADPH regeneration. J Ind Microbiol Biotechnol 34:83-90

Xu Z, Zhong Z, Huang L, Peng L, Wang F, Cen P (2006) sHigh-level production of bioactive human beta-defensin-4 in Escherichia coli by soluble fusion expression. Appl Microbiol Biotechnol 72:471-479. doi:10.1007/s00253-0050287-0.

doi:10.1186/2191-0855-2-12

Cite this article as: Muntari et al:: Recombinant bromelain production in Escherichia coli: process optimization in shake flask culture by response surface methodology. AMB Express 2012 2:12.

\section{Submit your manuscript to a SpringerOpen ${ }^{\circ}$ journal and benefit from:}

- Convenient online submission

- Rigorous peer review

- Immediate publication on acceptance

- Open access: articles freely available online

- High visibility within the field

- Retaining the copyright to your article

Submit your next manuscript at $\gg$ springeropen.com 